\title{
Is Environmentally Sustainable and Inclusive Growth Possible? Sub-Saharan Africa and Emerging Global Norms on Development
}

\author{
Mzukisi Qobo* \\ University of Pretoria, Centre for the Study of Governance Innovation
}

\begin{abstract}
This paper critically reviews the debates on environmentally sustainable and socially inclusive growth with specific focus on Sub-Saharan Africa. It observes that even considering its inherent limits, the discourse on growth is still imprisoned by the Washington Consensus mode of thinking. There have been attempts by various institutions and commissions appointed by heads of governments to take the debate forward, but a lack of commonly agreed global norms undermine prospects for shifts in thinking. Nonetheless, countries need to undertake such efforts within if there is to be any meaningful deliberation on environmentally sustainable and socially inclusive growth. In this regard, the paper also examines the strengths and weaknesses of efforts undertaken by South Africa thus far. Policy emphases on the role of the state and structural transformation that predominate debates in formal institutions in the African continent are insufficient. As such, this paper explores what is possible.
\end{abstract}

Key Words: Sustainable development, Inclusive growth, Environmental sustainability, Africa's development, Structural Transformation, Developmental states

\section{Introduction}

In recent times, and especially in the wake of the 2008 global financial crisis, there has been much talk about the need for a new growth model. There is, however, very little work done on what this means precisely. Much of the critical work on economic growth has focused on either recasting the relationship between the state and markets, with more of a role for

\footnotetext{
*Mzukisi Qobo <mzukisi.qobo@gmail.com>
} 
institutions in facilitating economic progress, ${ }^{1}$ or more recently, a critical evaluation of the use of gross domestic product (GDP) as a single measure of how well countries are doing. ${ }^{2}$ In sub-Saharan Africa, many countries have since independence battled with this complex question: how to grow their economies sustainably and develop their people. There have been many initiatives in the past, some home-grown, and some representing a mixture of home-grown ideas and externally-driven initiatives. South Africa has also had to contend with this challenge, especially because of the socio-economic complexities it faced postapartheid, the imperative of growing the economy and generating employment opportunities, and reducing social inequalities.

The theme of environmentally sustainable and socially inclusive growth is once again receiving attention from both Northern and African institutions. The paper argues that the discourse on growth is still imprisoned by the Washington Consensus mode of thinking. Even when the shift in discourse is towards the need for a greater state involvement in development, as is evident in most of the recent literature from Africa's institutions such as the African Development Bank, this perspective sometimes ignores the different realities that obtain in various African countries, especially the fact that some do not have the problem of an absent state but of weak productive capacities and shallow markets.

The paper is divided into the following sections. The first, looks at the concept of socially inclusive and environmentally sustainable growth. Different approaches and their strengths and weaknesses are evaluated. Second, the paper then looks at the politics of sustainability and poses questions about the most sustainable measures that nations need to undertake both at the levels of production and consumption. Interplays of power in setting global standards as well as political economy tensions at the domestic level are discussed.

The third section assesses Africa's development challenges, in particular weak governance infrastructure and reliance on a narrow range of products as a structural impediment to development. The fourth section paints Africa's positions on climate change, in particular focusing on how the continent's developmental vulnerabilities define its leaders' negotiating positions at the multilateral level. The fifth section reflects on some of the emerging paradigms on Africa's development driven by African institutions. The growing emphasis on the role of the state comes under spotlight. 
This section in particular critically discusses positions of the African Development Bank (AfDB) and those emerging from within the UN Economic Commission on Africa (UNECA). The sixth section takes a closer look at some of the policy measures that have emerged within South Africa, and observes how limited the debate on inclusive growth and environmental sustainability is. Here the paper focuses on the New Growth Path and the National Planning Commission's National Development Plan, which are both centre-piece institutions to achieve growth and development. The final section draws the various strands of the discussion together and highlight pillars of a strategy to achieve inclusive and environmentally sustainable growth.

\section{Socially-inclusive and environmentally sustainable growth}

There have been a number of attempts to define measures of prosperity beyond a narrow focus on GDP growth. These are summarised in the work of Lorenzo Fioramonti, who has undertaken a systematic documentation of the history of GDP. ${ }^{3}$ At the policy level, discourse on development tends to also be overly obsessed with outcomes to the disregard of process. The former has more to do with quantifiable indicators of the state of the economy, for example the rate of economic growth, and measures of progress in the delivery of certain government services. As Helpman notes, raising income per capita is generally seen in economic orthodoxy as a proxy of how well people live, and factors such as accumulation of physical and human capital as major forces behind income growth. ${ }^{4}$ The latter approach to development, valuing process, is more concerned about ideas, values (for example freedom or depth of political participation), the kind of institutional framework involved, and the nature of social relations (including state-society) required to empower citizens over time. A cohesive policy framework on how exactly to go about that remains elusive.

Even in some of the latest attempts by the Organisation of Economic Cooperation and Development (OECD) to frame new thinking on inclusive growth, there is no new ground broken on this subject. The report, entitled 'Promoting Inclusive Growth: Challenges and Policies', examines inclusive growth from various dimensions, including political economy, finance and regulation, inclusive green growth, fiscal policy, public intervention, and competition and innovation. ${ }^{5}$ Yet its conclusions affirm the broad outlines of the economic 
orthodoxy that stress macro-economic stability and chasing of economic growth as narrowly conceived.

One key emphasis of the report is the fact that inclusive growth is multidimensional, and should be seen as going beyond issues of poverty and income distribution, and placing emphasis on social cohesion and well-being. It also stresses a definition of inclusive growth as growth that is sustainable and broad-based in terms of employment opportunities. In the past, much of the thinking around growth has centred largely on a set of policy prescripts based on economic orthodoxy, sometimes in its 'improved' version. Dimensions such as fiscal discipline, reorientation of public expenditure, tax reform, interest rate liberalisation, unified and competitive exchange rates, trade liberalisation, openness to direct foreign investment, privatisation, deregulation, and secure property rights have come to form the cornerstone of what is termed the Washington Consensus.

As Rodrik notes, in its improved form the Washington Consensus included elements such as corporate governance, anti-corruption, flexible labour markets, adherence to WTO policies, adherence to international financial codes and standards, emphasis on prudent capital account opening, non-intermediate exchange rate regimes, independent central banks/inflation targeting, social safety nets, and targeted poverty reduction. ${ }^{6}$ These were sold as holding the possibility of helping to improve the growth of nations, especially developing countries. Already there was recognition among the advocates of these policies that 'market-oriented policies might be inadequate without more serious institutional transformation, in areas ranging from bureaucracy to labour market. ${ }^{7}$ Inclusion of social policies and anti-poverty measures lend a human face to an approach that for a long time focused on aggregate figures and placed faith in trickle-down effects of growth.

Yet, however many attempts are made to introduce new measures to help promote growth, establishing institutions that ensure inclusivity and sustainability are not possible in domestic political settings where the relationship between the state and society is weighted in favour of enhancing the well-being of state elites - what Daron Acemoglu and James Robinson characterise as extractive political institutions. ${ }^{8}$ Redefining the terms of growth will need to begin at the domestic level with a change in the structure of political relationships, especially the need to enhance citizens' capabilities, freedoms and voice so 
that they can effectively participate in legislative or policy processes about social and economic policy. Improving both the central and local institutions should be the starting point in rethinking growth models.

Drawing on her personal experience in driving economic reforms in Nigeria since 2003, Nigeria's finance minister Ngozi Okonjo-Iweala highlights the following steps as critical for turning failing countries around: managing public finances better through transparency and tighter fiscal management; deregulating backbone infrastructure sectors, in particular telecommunications; setting up institutions aimed at fighting corruption; lock-in reforms legally to prevent reversals; and reorient focus to job creation in particular in the real sectors of the economy. ${ }^{9}$ This is an approach that confirms the importance of home-grown measures in managing economic change in the African countries. What is also important is that macro-economic reforms are strongly complemented with micro-economic interventions, in particular those aimed at diversifying the economic structure; improving human capital; and achieving greater inclusion of the marginalised in economic participation.

Much of the thinking about growth thus far has tended to be top-down driven, disregarding citizen voice and participation. As such, there have been very few attempts at redefining GDP models and putting in place an alternative framework of measuring well-being. Some of the more innovative approaches have failed to capture the centre-stage of academic thinking or policy formulation. Fioramonti notes that the first internationally renowned attempt at revising GDP was made by William Nordhaus and James Tobin in 1971. These two economists developed an index called Measure of Economic Welfare (MEW), which reclassified expenditures 'as consumption, investment and intermediate' in order to achieve a better distinction between final and non-final (intermediate) goods. ${ }^{10}$

They did not dispense with GDP measures altogether, save to point out that they were insufficient and needed re-ordering. Their measure of economic welfare was more of a rearrangement of items in the national accounts to demonstrate that economic growth needed to remain a fundamental objective of policy, while a better understanding of welfare could be simply obtained with limited (largely technical) adjustments. A more textured elucidation of the concept of development is advanced by Amartya Sen, based on 
the notion of expanding human freedoms, choice, and capabilities as opposed to more evaluative definitions that narrowly privilege certain outcomes such as gross national product; rise in personal incomes; industrialization; and modernization. ${ }^{11}$ Sadly most countries in the African continent, even leading reformers, have not gone much beyond this narrow framework of development. The picture is made more complex by the constraints imposed on development that are overly dependent on non-renewable resources that have long-term environmental consequences.

Economists such as Sen have insisted on looking at both income poverty and capability poverty. Sen argues, for example, that '...the reduction of income poverty alone cannot possibly be the ultimate motivation of anti-poverty policy...capability improvement helps both directly and indirectly in enriching human lives and in making human deprivations more rare and less acute'.$^{12}$ In response to these weaknesses of exclusively income-based measurements, the basic needs approach was developed and proposed by the International Labour Organisation (ILO) in 1976 at the World Employment Conference. The basic needs approach introduced the idea that employment in and of itself was not a sufficient goal but was rather a means for people to meet their basic needs which included food, clothing, housing, education and public transportation. This approach later came to include concepts such as decision-making.

The UN Human Development Report based its approach to human development along three dimensions: life expectancy, educational attainment and command over the resources needed for a decent living. It is more predisposed to a capabilities approach as championed by Amartya Sen among others. It does not just take the GDP measure as a given but also looks to privilege notions of human well-being and freedom. ${ }^{13}$ This is not to suggest that evaluative outcomes are not important, but that the primary objective is to remove constraints impeding the realisation of freedom and expression of human capabilities. It is thus the ability to exercise choices to achieve one's objectives and to fully express one's capabilities without the limit of artificial or structural constraints that should constitute the essence of development rather than a GDP figure moving up and down.

While GDP growth may have a positive effect when trickling down through employment or expanded economic activities that help to generate more revenue for the government 
(towards for instance social expenditure, investment in knowledge, expanding infrastructure), in conditions of weak capabilities it has a very limited positive effect. Where levels of education are low, voice is absent, and man-made institutional or regulatory mechanisms are constrained, thus limiting full expression of potentialities; GDP becomes a poor handmaiden for facilitating inclusivity and sustainable development. At the policy level, governments and citizens have to explore ways to enhance effective participation in democratic processes as well as to make it easier for citizens to participate in economic activities.

As documented by Fioramonti, among civil society groups, Social Watch has been publishing a Basic Capabilities Index (BCI) since 2000, which covers over 170 countries. Instead of GDP, Social Watch's approach proposes measurement of income, focusing on the 'different aspects of people's actual condition and their greater or lesser possibility of having their human rights fulfilled. ${ }^{14}$ The index consists of three indicators: the percentage of children reaching fifth grade, survival until the age of 5 , and the percentage of births attended by skilled personnel. This index dispenses of income as an indicator, and places more emphasis on human capabilities tracking the United Nations Millennium Development Goals. Essentially, this measure focuses on qualitative processes and outcomes.

\section{The Politics of Sustainability}

The focus on growth looks at questions of accumulation in a very linear logic; for example, assuming that the more a country produces, consumes or exports, the greater the propensity for growth. Sustainability, on the other hand, is more concerned with consumption, the method and the content of production, and trade-offs that need to be made today to ensure that future generations are not sacrificed at the altar of short-term prosperity. The other way of looking at it is in terms of trade-offs that various countries have to make if prosperity is to be broadly shared and long-lasting.

Like growth, sustainability can be an omnibus concept that encompasses ecology, production methods, what and how nations consume, and the risks to a country's resources. On sustainability, there remain serious contestations on what precise measures countries should take to shift away from unsustainable production and consumption patterns. There is also no definite framework to manage collective action on a global scale to promote 
sustainable development. One of the challenges with normative concepts such as these is that they are heavily contested and their definitions tend to be elastic. Although the United Nations Framework Convention on Climate Change (UNFCCC) negotiating process has established a basic convergence point on the menacing reality of climate change, for instance, it is fraught with tensions and diplomatic posturing. There are no agreed and legally binding measures on greenhouse gas emissions. In the end negotiations are subjected to interplays of interests in the domestic political economy, as well as the interplay of power between major economies that are either major emitters or have a significant historical carbon footprint.

Nonetheless, sustainable development gained currency towards the end of the 1980s with publication of the Brundtland Commission Report, 'Our Common Purpose', which drew linkage between the three pillars it identified - the environment, the economy and society. Subsequent summits, beginning with the Rio Earth Summit of June 1992, were held to negotiate a shared platform to protect the environment while tackling challenges of growth and development.

Achieving objectives related to 'sustainable development' at a global level is a difficult commitment to realise due to the fact that countries are at different levels of development, and they have to negotiate trade-offs with a range of constituencies at the domestic level. Further, states have differential capabilities to develop, and policy goals that they themselves set at the domestic level in order to achieve 'sustainable development'. Yet sustainable development at the global level remains an important theme that expresses the interdependence of nations and requires collective action.

The emerging paradigm of socially inclusive and environmentally sustainable growth is, no doubt, gaining wider currency. The OECD recently published its comprehensive report on social inclusiveness and environmental sustainability in growth. It observes that economic vulnerabilities and inequalities no longer just affect poor countries but advanced industrial economies as well. In OECD countries, for example, the income of the top $10 \%$ has risen to nine times that of the bottom $10 \%$, with unemployment remaining structurally high. The OECD defines inclusive growth as a multidimensional concept which goes beyond poverty and income distribution and emphasises social cohesion and well-being. It further suggests 
that balancing growth across different economic activities is also an element of inclusiveness. It lays a stress on the need for specific institutional solutions to important market failures as well as the need for governance capabilities. ${ }^{15}$

While helping to promote different ways of thinking about growth, with its emphasis on social inclusion, one of the weaknesses of the OECD report is that its thinking is still beholden strongly to state or centrally-driven processes. It relies too heavily on state institutions or industrial planning as bearers of solutions for inclusivity, with very little to say about the capabilities of citizens and civil society institutions. With the exception of a few prominent scholars who are appointed to commissions set up by heads of governments, by and large, civil society's voice is on the margins of the mainstream debates on environmental sustainability and social inclusivity. Some of the individuals who have become prominent in government-created commissions about sustainability include Joseph Stiglitz, Amartya Sen, and Michael Spence. There is a need to engage civil society more closely at both global governance level and domestic level on the meanings of these concepts and the shape of policy measures.

The debates run parallel, with civil society having a dialogue within. The private sector has its own initiatives towards promoting a sustainability agenda, although much of this effort is limited to creating awareness and managing environmental risks that could have an impact on companies and their cities. One such initiative is the carbon disclosure project. This is a platform enabling companies and their cities to measure, disclose, manage and share information on environmental issues. The activities of the network range from working to make institutional investors more aware of environmental risks, to encouraging supply chains of large multinational companies to take into account those environmental risks. ${ }^{16}$ There have been various other initiatives driven at the global level on rethinking the models of growth, to place greater stress on sustainability and inclusivity. A survey of a few of these follows.

\section{Towards a new paradigm}

Apart from Amartya Sen, economists such as Michael Spence and Joseph Stiglitz have also contributed to advancing a new paradigm on environmentally sustainable and inclusive growth. 


\section{Commission on Growth And Development}

The Commission on Growth and Development (CGD) was launched in 2006 at the behest of the World Bank, and comprised practitioners from government, business and other policy makers from across the developing and developed world. It was chaired by Nobel Laureate Michael Spence. According to the commission, to have sustained growth and direction, policy needs to be clear, coherent and adaptive. Since growth is not static and there are moments when it does decline, what is perhaps implied by sustained growth is that declines should not leave citizens or nations worse-off; there need to be other measures of wellbeing that are factored into policy thinking.

For any leadership to successfully design and implement environmentally sustainable and socially inclusive growth, according to the CGD Report of 2010, it must possess the requisite level of political will and it must be capable of managing change. The focus of the report is mainly on government leadership, macro-economic reforms, and global risks that affect both the developing and the developed world. The approach taken by the CGD is that national leaders must do more than simply pursue economic growth as an end in itself. Sustained results are possible when there is long-term planning, national vision, and institution-building. As the CGD report further notes, growth is not an end in itself but an instrument to create resources that improve well-being.

Nonetheless, among the more prominent global initiatives to generate new thinking about growth strategies, the CGD report is perhaps one of the few that has a dedicated section on Sub-Saharan Africa. It highlights the strides that the African continent has made since the mid-1990s in fostering economic growth through micro-economic policies and prudent macro-economic management, and the gains made in higher commodity prices - achieving a growth spurt that was only slowed by the outbreak of the global financial crisis.

\section{Sarkozy Commission}

In another example of initiatives to rethink models of growth, the former French president, Nicolas Sarkozy, appointed a commission led by Joseph Stiglitz as its president, Amartya Sen as advisor, and Jean Paul Fitoussi as its coordinator. The starting point of this report in 2008 was that measures of GDP were not adequate, and do not fully account for well-being. The 
report pointed out that 'choices between promoting GDP and protecting the environment may be false choices, once environmental degradation is appropriately included in our measurement of economic performance'.

Specifically, the report assesses current well-being, in terms of resources, income and quality of life, as well as how stocks of capital are transferred to later generations. It is certainly a useful contribution to the current analysis of growth and development thinking. The authors of the report underscored the urgency of measuring the quality of economic output, which is a variable usually ignored in GDP measurements. The core message is the need for a shift from measuring economic production to measuring people's well-being. Commissioners Stiglitz, Sen and Fitoussi accorded importance to the maximisation of human capabilities, implying that an absence of constraints to maximising choice and human capabilities is what constitutes development. ${ }^{17}$

The Sarkozy Commission provides a few recommendations on how to measure well-being. The first aims at material well-being. Where most measurements look at production figures, the report recommends analysing income and consumption patterns. This preference incorporates price volatility and differences between, say, production and consumption. It is possible, for example, that an economy is growing at impressive rates - as is the case in parts of the African continent - but citizens do not have sufficient incomes to purchase food either because an economy is powered only by one sector (resources) and with weak absorption capacity in the labour market, or due to food price volatility.

Lack of access to grain and other basic food stuff may well be driven by exogenous factors such as high energy prices or the practice of hedge funds and speculators through commodities exchange platforms. The Sarkozy Commission recommended analysis of household income to ascertain the level of subsidies and welfare benefits government should distribute to such households. This applies a different way of determining well-being or deficiencies that does not necessarily use as its point of departure variables such as GDP per capita.

As the Sarkozy Commission suggests, the consumption of goods that carry only short-term utility does not benefit the long-term stocks of a household's balance sheet. At the same time, long-term stocks are either assets or liabilities that affect the scope for consumption in 
households. In Africa, there is very little continuity of long-term stocks other than land and cattle as economies struggle to develop and increase material gain in wealth beyond agricultural assets. Further, GDP statistics do not account for unequal distribution of income which also applies to Africa, where some countries might display GDP growth, but the benefits of growth accrue to the elite while the majority of the citizens remain trapped in poverty. The method preferred by the commission was to take into account the median income, consumption and wealth of households.

Such a figure would be more representative of the differences between high-income and low-income households as well as those between low-income households with more sustainable wealth and those without; these differences would indeed be great in African homes. Notions of income support are now part of discussions on global governance, sometimes framed as social safety nets largely targeted at those without jobs or who have just lost an employment opportunity.

The report emphasises the multi-dimensional nature of well-being by encompassing material well-being; education; health; personal activities (including work); political voice and governance; social connections and relationships; environment; and security. Developing a comprehensive network of linkages across all factors of well-being will enable aid policy-makers to better understand the effects of economic disadvantages within a society and economy, regardless of the overall growth rate. These are also factors that need to be taken into consideration in thinking about a global agenda for environmentally sustainable and inclusive growth.

\section{African development in a changing international context}

\section{Contextualising Africa's Development Thinking}

Commentaries on the state of Africa's development abound. These range from pessimistic views that regard Africa as a dark continent with very little chance to succeed in the world economy to a more upbeat perspective in more recent times that considers Africa as the next frontier of growth. Such views have been largely shaped by the hesitant start of the continent in its post-colonial journey in the late 1950s and early 1960s. The initial era of hope that came with independence for most African countries was short-lived and was to be 
quickly eclipsed by a wave of violence, ethnic strife, coups, and famine in large parts of the continent. This was compounded by the long period of world recession that began with the 1973 oil crisis, spiralling into debt crisis for Africa. The period between 1970 and 1980 came to be known as the 'lost decade', and was followed by a series of policy experiments with structural reforms by the World Bank and the International Monetary Fund, often with unfruitful - or deleterious -- outcomes.

Quite apart from inheriting political and economic structures that were not viable, one of the major weaknesses that, perhaps, explains the lack of social and economic progress on the continent at that time was the failure to build a solid infrastructure of governance. The institutional framework necessary to run national governments and create a healthy interface between the governing and the governed took a long time to emerge. Leadership plays a crucial role in establishing a framework of governance that is effective, and that leads to desirable economic outcomes for citizens. Visionary and responsible leadership is, according to Rotberg, a critical missing ingredient for many African countries, making it harder for them to progress on a march to development. ${ }^{18}$ Rotberg further points out: "Economic advances follow policies enunciated by the same gifted kinds of leadership, especially in the myriad small, challenged states of Africa. Poverty can hardly be alleviated without a committed political leadership that understands the close connections between macro-economic prudence, strengthened rules of law, and prosperity." ${ }^{19}$

Another factor that has contributed to Africa's lack of progress has been its dependence on a few primary exports; many African economies lack structural diversification. Primary commodities are highly susceptible to price fluctuations, with adverse effects on foreign exchange earnings. As Jeffrey Frieden points out, 'The colonial political economies had relied on exporting primary products to the mother country: copper from Congo to Belgium, coffee from Kenya to Britain, cocoa from Cote d'Ivoire to France, petroleum from Angola to Portugal. $^{20}$

Countries such as Benin, Burundi, Cameroon, Cote d'Ivoire, Ethiopia, the Gambia, Ghana, Kenya, Mozambique, Niger, Senegal, Sudan, Tanzania, Uganda and Zimbabwe have also shown a strong predilection towards export of primary commodities. ${ }^{21}$ These primary 
product exports are mainly destined for Europe. Despite decades of trade and aid relationships with Europe, Africa's economies have not achieved diversification. Africa's intimate commercial ties with former colonizing nations epitomised Africa's dependence on external actors. Such relations contributed little to advancing Africa's development and changing its production profile. Countries such as Nigeria and Angola may be the second and third largest economies in Sub-Saharan Africa, respectively, but long-term prosperity in these countries could well be undermined by their heavy dependence on the oil sector whose price is determined by exogenous factors.

The period between 1999 and 2008 saw the continent's fortunes begin to change somewhat. This period signalled economic revival on the continent, with a promise that Africa's poor would at last be rescued from marginalisation. This revival can be credited largely to political liberalization, macro- and micro-economic reforms, and the commodity boom which has mainly been driven by Asia's emerging economies. The high average growth rate on the continent between 2000 and 2008, at roughly $6 \%$, is thus far the high water mark for Africa's economic fortunes. As important as it was as a confidence builder, however, this period of high growth was not sufficient for ensuring environmentally sustainable and inclusive growth.

Growth had a soft impact on reducing income inequalities and very limited impact on poverty reduction, especially if there are no complementary policies to support incomes, create jobs and invest significantly in education. Countries such as Angola and Nigeria that are experiencing levels of growth at $8 \%$ and $7 \%$ respectively still boast high levels of income inequality. Indeed in the case of Nigeria the decade of what looked like an impressive macro-economic reforms did not translate into massive job creation and poverty reduction. Income inequality was reduced slightly from 0.49 in 2004 to 0.45 in $2010 .^{22}$ This is precisely because of a lack of institutional capacity and few policy measures designed to ensure the proceeds of growth are broadly shared, or at the minimum that income support is an integral part of policy. In large measure growth in Nigeria reflects activities that are taking place within the natural resources sector, which has a limited employment generation pull or spill over effect to other sectors of the economy. In this sense, commodity-driven growth cannot be said to be socially inclusive as proceeds are often captured by oil-interfacing elites. According to the African Development Bank, 'Growth is inclusive when it creates 
economic opportunities - the pace of growth - while ensuring equal access to them - the pattern of growth. ${ }^{23}$ Both the pace and the pattern of growth are important in ensuring meaningful change in the quality of life.

The global financial crisis that followed in 2008 affected the African continent adversely, although the effects varied as will be discussed below. Even though the crisis had its origins in advanced industrial countries, given Africa's institutional vulnerabilities the effects on many economies on the continent were particularly intense. As underlined by the 2010 Economic Commission Report on Africa, these effects included a slowing down of trade, increases in food and fuel prices (which had been reducing since late 2006), weakening demand for exports in goods and services, decrease in remittances, and reduced private capital inflows. ${ }^{24}$ In turn, employment conditions became dire as trade finance seized up and production was scaled back. Indicative of hard times on the continent, GDP growth rates in 2009 averaged 1.6\%, which was a far cry from a year earlier where the continent grew by $4.9 \% .^{25}$

There are common themes that may help to map out key developmental priorities for the African continent, as well as help in discerning a normative agenda that reflects both the current state of the continent and the possible direction(s) of change in the future. One of these themes relates to Africa's dependence on a narrow range of agricultural products and natural resources. This is a perennial challenge which was seemingly ameliorated with the rise of emerging economies and their huge appetite for Africa's resources. Another theme is Africa's vulnerability to global financial trends, in general, as seen in the derailing of economic progress on the continent following the global financial crisis. The onset of the global financial crisis took the world by surprise, and Africa was ill-prepared for its effects. The crisis laid bare an age-old problem of Africa's lack of product diversification and heavy reliance on natural endowments rather than competitiveness factors. This also confirmed the need for the continent to diversify its export markets rather than depend on just a few destinations. Declining capital flows underscored the importance of domestic resource mobilisation for the continent in order to finance growth and employment projects on a more sustainable basis. 


\section{Africa and Climate Change}

Africa is vulnerable to climate variability and change with serious implications for economic and social development. There are many countries in Africa that are susceptible to droughts, floods and other extreme weather conditions. As such, environmentally sustainable and socially inclusive growth will be secured only when there is a serious commitment to help Africa to mitigate climate change and put in place sound adaptation strategies. As the UN's Economic Commission for Africa (UNECA) Report of 2010 points out: '...climate change could undermine growth and development prospects, thereby slowing progress towards sustainable development' ${ }^{26}$

African leaders took a decision to negotiate as a bloc on climate change issues when they met in Algiers under the aegis of the African Ministerial Conference on the Environment in November 2008. This position was further consolidated in May 2009 when the Ministers of the Environment met again in Nairobi and issued a declaration that was to inform their negotiating positions in the climate change negotiations that were to be held in Copenhagen, in December the same year.

In short, Africa's positions on climate change are structured to emphasise vulnerabilities that various countries suffer with respect to the interlinked challenges of drought, food security and poverty. The Nairobi Declaration called for industrialised countries to cut their emissions by $25 \%$ to $40 \%$ below 1990 levels by 2020; to increase finance for adaptation; to provide for capacity building for mitigation purposes; and to provide equitable compensation for environmental, social, and economic losses. Given weak institutional and policy capacity it remains unclear, however, how various African countries are evolving policies aimed at limiting climate-change related risks.

Africa's vulnerability regarding climate change is made worse by the fact that a number of countries tend to rely on agriculture, forestry, and fisheries - all products that are climate sensitive. The 2010 UNECA Report further notes that as a result of climate change, around 250 million people in Africa could be exposed to water stress by 2020, with this figure expected to rise to between 350 and 600 million by 2050, especially affecting North Africa and Southern Africa. ${ }^{27}$ 
Disruption in rainfall accentuates the strain, as most of Africa relies on rain-fed water sources. Consequent to climate variation, flooding could have a disruptive impact on production and employment patterns, with incomes possibly declining. Adaptation to climate change in Africa is expected to cost between $5 \%$ and $10 \%$ of the entire continent's GDP, with actual costs averaging around US\$75bn-US\$90bn from 2010 to 2050, according to the World Bank. ${ }^{28}$ The World Bank study was conducted in partnership with the governments of Bangladesh, Bolivia, Ethiopia, Ghana, Mozambique, Samoa, and Vietnam; it was funded by the governments of The Netherlands, Switzerland, and the United Kingdom. According to the findings of the study, the intensification of climate-related funding becomes an absolute necessity for the African continent as does the need to transfer technology to facilitate decarbonisation of the economies, especially in countries such as South Africa that are major contributors to green-house emissions. For much of Africa technology transfer for mitigation purpose is an absolute imperative if these countries are to weather the storms in the future.

While the notion of environmental sustainability is widely accepted by African policy makers, however, commitment to change remains only at the level of rhetoric it would seem, used largely as a diplomatic instrument to attract greater financial assistance to African countries rather than informing policy or domestic institutional processes.

\section{Bringing the state back into development?}

UNECA, which represents an important intellectual perspective on the continent on Africa's development, has in the wake of the global financial crisis placed considerable weight on the role of the state as a catalyst for the continent's development. Apart from those vexed issues related to the global financial crisis and climate change that conspire to undermine Africa's development prospects, there remain critical structural weaknesses in various African economies. Much of the emerging discourse within the continent on building resilience is placing a premium on the role of the state and on shifting the content of production away from dependence on a narrow range of agricultural products, which are so very vulnerable to climate change effects.

In the UNECA report of March 2011 focusing on 'governing development in Africa', three critical areas were identified to help Africa drive its development: 1 ) the need for 
diversification and structural transformation away from agriculture; 2) the potential central role of the state in this structural transformation; and 3) the imperative to construct a developmental state to boost economic transformation. ${ }^{29}$

While in practice, African countries have gained a better footing in their economic management through stabilising their macro-economic environments and market-based economic reforms, there has been a growing disappointment with the Washington Consensus models to development that places an emphasis on deregulation, market-based economic management, and liberal trade and investment policies, with limited impact on improving living standards for the majority of the population. The global financial crisis deepened the emerging global consensus that this model is no longer applicable. Nevertheless, it is not clear as to what body of ideas would arise in place of the Washington Consensus; there is also no particular consensus on the primacy of the state in economic management. Even within the Bretton Woods Institutions (BWIs), there are calls to go beyond the 'Washington Consensus' and to consider 'second generation reform programmes' and other attempts to 'stimulate state capacity', and return to the idea of development by the state that has been pushed by a wide range of scholars and institutions. $^{30}$

With respect to the African continent, especially in the more recent work of the Economic Commission on Africa, the rhetoric of statism is indeed gaining currency. This is accompanied by an emphasis on the need to upscale industrialisation and to look at geographic markets beyond traditional partners such as the European Union and the US. The major argument that is advanced by the Economic Commission on Africa is that the state is best placed to drive economic development in Africa.

It is notable however that, while UNECA is reviving statism and industrialisation, pointing to the example of China and South East Asian countries as paradigms of success worth emulating, other important African institutions place emphasis on a different set of priorities, in particular agricultural development as a catalyst to power Africa's economic resurgence. For example, the African Union and the New Partnership for Africa's Development (NEPAD) view Africa's development as achievable through an essentially agricultural-led programme. NEPAD's Comprehensive African Agricultural Development 
Programme, for example, seeks to promote greater private sector investment in Africa's agriculture, grow emerging farmers, and address food security concerns.

At the same time, this may be undermined by the consensus emerging in the African continent that even though agriculture needs to be revived and made more productive, depending just on primary products for exports is untenable. Thus even within agriculture there is a growing focus on developing agro-processing and adding value to production processes.

It must be noted at this point that UNECA's view is grounded, primarily, in ideology and an obsession with a romanticised 'developmental' state more than in the realities of prevailing conditions on the continent, namely, the weaknesses of the state and the absence of solid institutions to manage economic change.

Mkandawire identifies three major challenges that have confronted the state in Africa: 1) the lack of developmental policy that facilitates and promotes economic growth and structural transformation; 2 ) the lack of development programmes that are democratic in a manner that makes the state derive legitimacy through popular participation and electoral processes; and 3) the absence of social inclusiveness that ensures equitable entitlements to citizens, leading to the exclusion of critical capacities and constituencies of the African population. ${ }^{31}$ The infrastructure of governance, and the kind of state-society relationships that exist in large parts of the continent, militate against the emergence of an accountable and capable state that can successfully drive economic development in an environmentally sustainable and inclusive sense, Mkandawire contends.

It is instructive to look at South African, Africa's largest economy, for more insight into efforts to achieve this goal of socially-inclusive and environmentally sustainable development.

\section{Socially-inclusive and environmentally sustainable development: Debates in South Africa}

Looking specifically at South Africa, many policy discussions around inclusive and sustainable growth centre on employment, poverty reduction and the advancement of social and economic equity. Unemployment has been one of the most vexed challenges, hovering at above $25 \%$, with youth unemployment estimated at $50 \%$. So far, the main policy 
framework to guide action has been the New Growth Path of the ruling party, the African National Congress (ANC), which is premised on increasing employment through the following elements: public investment in infrastructure; supporting key economic sectors such as mining, agriculture and manufactures; pursuing opportunities in the 'knowledge' and green economy; investing in public services and the non-governmental sector; and prioritising rural development.

\section{The New Growth Path}

The New Growth Path document highlights some of the challenges facing the South African economy, pointing out that the economic recession that began in 2008 had a significant impact on South Africa's economy, with 1 million jobs lost between this period and 2010 . While overall unemployment in South Africa, as per official figures, still hovers at above $25 \%$, Rankin et al believe that unemployment of those between the ages of 24 and 35 is roughly $71 \% .^{32}$

At its core, the National Growth Path $^{33}$ seeks to design a policy package to facilitate employment creation that would be achieved by enhancing social equity and competitiveness; mobilizing domestic investment around sustainable job creation; and fostering social dialogue among stakeholders to encourage growth in employment creating activities. Some of its aspirations include:

- Accelerating employment creation through direct employment schemes, targeted subsidies and more expansionary macro-economic package;

- Supporting economic activities in the agricultural value chain, light manufacturing and services; generating large-scale employment; and providing inducements to the private sector;

- Supporting knowledge- and capital intensive sectors, as full employment is achieved.

Further, this policy document also alludes to accelerating industrialization and finding markets in Brazil, India and China. This ignores the fact that these countries are South 
Africa's competitors especially in sectors such as steel, auto, pharmaceuticals, and clothing and textiles. Moreover, South Africa suffers competitive disadvantages in its distance from bigger markets, its labour market inefficiencies, and volatile exchange rate.

\section{National Planning Commission}

Simultaneously with the development of the New Growth Path, South Africa's President Jacob Zuma appointed the National Planning Commission (NPC), with the former Minister of Finance Trevor Manuel as the head. The mandate of the Commission was to develop a longterm national plan that would in turn set out a vision and a long-term planning framework for government for the next twenty years. The NPCs discussion and recommendations in the National Development Plan ${ }^{34}$ go further than the New Growth Path, covering environmental, economic and social issues.

Both policy frameworks recognise the need to shift incentives to privilege sectors that have less strain on the environment, and that could place South Africa on a low-carbon trajectory. In the New Growth Path, for example, green growth and the social sector are identified as two of the five drivers of employment growth in the future. The 'green economy' is identified as one of the six priority economic sectors with projections of 300000 new jobs by 2020 . In a complementary vein, the NPC seeks to explore measures to reduce the resource-intensity of the economy and support initiatives related to diversifying South Africa's energy mix in order to reduce coal-dependence. The efforts of the NPC are not without hurdles. One of the difficulties has to do with getting support from other departments. There is a hint of doubt in the National Development Plan about the role of nuclear, yet Pretoria's Department of Energy is pursuing this path. It needs underscoring that the National Planning Commission possesses no implementation authority.

The publication of the National Development Plan was preceded by a diagnostic report published in June 2011, the aim of which was to offer an assessment of how far South Africa had come as a country since 1994 and to point to some critical gaps that still require attention. In trying to make sense of the current situation in South Africa, the NPC has also introduced what it calls 'indicators of decline': (1) rising corruption; (2) weakening of state and civil society institutions; (3) poor economic management; (4) skills and capital flight; (5) 
politics dominated by short-termism, ethnicity or factionalism; and (6) lack of maintenance of infrastructure and standards of service.

While trying hard to paint a positive picture, the NPC could not avoid the dire conclusion that: 'elements of these indicators are already visible in South Africa'. Further, the diagnostic report observed that South Africa suffers from: poor education outcomes, a high disease burden, divided communities, uneven public service performance, the existence of spatial patterns that marginalise the poor, under-employment of South Africans, and a resource-intensive economy.

The National Development Plan for Vision 2030 covers about 15 areas that require government's intervention and prioritisation. The first section sets the tone for the rest of the plan and identifies key drivers that will supposedly bring about substantive change in the economy: international political and economic developments; globalisation; Africa's development; climate change; and technological change.

The rest of the framework discusses shifts in demographic trends; economy and employment; economic infrastructure; transitioning to a low-carbon economy; inclusive rural economy; defining South Africa's place in the world; human settlements; improving education; and promoting health; social protection and environmental sustainability. Addressing structural unemployment will, according to the framework, require better educational outcomes, a healthier population, and good quality infrastructure. It places hope on the increase in the rate of investment as a proportion to the GDP; and further projects an employment scenario of 11 million new jobs by 2030 . There is very little implementation detail in the framework, and the likely factor that could act to undermine its potency in addressing challenges of weak growth, unemployment and inequalities are institutional weaknesses of the state.

\section{South Africa and Sustainable Development}

Sustainable development and growth have been important aspects of the policy debates within South Africa, particularly because there has been recognition that the current pattern of economic growth based on carbon intensive methods is not sustainable in the long term. South Africa conceives sustainable development as involving trade-offs along the three 
internationally recognised pillars of sustainable development, namely: social, economic and environmental dimensions.

South Africa is in a difficult position with regard to achieving sustainable development outcomes while simultaneously pursuing robust growth. The country's economy is resource and carbon-intensive. The South African economy has historically been and continues to rely on cheap and abundant coal, most of which has kept the mining sector humming. The National Planning Commission envisages a loosening of this dependence by 2030 with greater diversification in the energy mix, and less reliance on resource-intensive sectors such as mining.

Currently, cheap sources of energy are a competitive advantage for the country. Significantly, mining continues to be an important source of foreign revenue, jobs and investment and is likely to play this role for the foreseeable future. This means that South Africa is trapped in an unsustainable pattern of growth and development, and would find it difficult to meet any legally-binding agreement at the global level on carbon emissions reduction. This is especially so since government commissioned the development of the expensive Medupi and Kusile coal-fired power stations in order to meet energy needs for development in addressing inequalities of the past through electrification programmes.

South Africa is aware of its vulnerabilities. As a country that plays an active role in multilateral processes and projects itself as a responsible international stakeholder, it participates actively as a non-Annex 1 country in the UNFCCC processes and is a signatory to the Kyoto Protocol. At the Copenhagen summit, South Africa made a voluntary commitment to reducing its carbon emissions below a baseline of $34 \%$ by 2020 and $42 \%$ by 2025 These targets are enormously ambitious given the carbon intensity of the economy. Complementing its approach to climate change negotiations, South Africa is a strong advocate for development financing and technology transfers from the developed world to developing countries in order to help with climate change adaptation and mitigation.

At the domestic policy level, South Africa has proposed a number of policies directly and indirectly related to environmental and energy issues. The National Climate Change Response Strategy for South Africa published in 2004 was the country's first attempt at articulating a coherent national response to climate change and forms the basis of further 
policy development on climate change and sustainable development broadly. ${ }^{35}$ In 2006 the Long-Term Mitigation Scenario (LTMS) was initiated and the report was released in 2008. The aim of this process was to investigate the possible mitigations strategies and interventions that South Africa could apply to reduce its carbon emissions and their impact on the economy and environment, so as to assess the implications of certain mitigation actions under consideration. In 2007 the Framework for Sustainable Development in South Africa was released. Its aim was 'to enunciate South Africa's national vision for sustainable development and indicate strategic interventions to re-orientate South Africa's development path in a more sustainable direction'.

South Africa's National Climate Change Response White Paper of 2011 has provided a more detailed assessment on the effects of climate change on key sectors and resources and actions that need to be taken to meet South Africa's long term development and mitigation goals. ${ }^{36}$ All these strategies and policies broadly express South Africa's views on climate change. They identify vulnerable sectors to climate change and propose actions that should be considered in order to mitigate negative outcomes. Even though the country has developed policies which seem to support notions of sustainable development there is a sense that the government has not done enough to create the sustainable, low-carbon economy it so often talks about.

\section{Towards a strategy for inclusive growth: The AfDB's view}

In its assessment of Africa's growth challenges and future prospects, the African Development Bank (AfDB) sounds an alarm regarding the bulging youth unemployment across the continent, and sends a warning that events that shook Tunisia and Egypt in 2011 could yet visit other countries whose structural conditions are similar to those that sparked widespread social discontent in the Arab countries.

While confirming the approach highlighted by UNECA that there needs to be a shift in the production structure away from a narrow concentration in extractive industries as this engenders vulnerability, the AfDB takes a different approach to the role of the state and markets in fostering development. Further, it places institutions and government in the frame as having an important role in facilitating conditions for prosperity rather than as actual drivers of economic activity. 
There are five all-encompassing pillars distilled from debates within the AfDB that can serve as a normative grounding for an inclusive growth approach - the kind of growth that is not just limited to specific and narrow sectors of the economy that generate very little spillover effect to the rest of the country.

\section{Conclusion}

There is no doubt a need to have a common framework of norms at the global level to deal with issues of sustainability, environment and inclusive growth. It is as important to place these on the global agenda as it is for political actors to show serious intent at the domestic level by incorporating these as part of policy planning. Much work has been done intellectually on conceptualising the meaning, the boundaries, and the policy elements entailed in the discourse of socially inclusive and environmentally sustainable growth.

One of the difficulties in implementing this agenda domestically and institutionalising it globally will be the painful trade-offs that need to be made and the tough negotiations that are required between diverse sets of actors at the domestic level. However, it remains necessary if there is to be a solid bridge of confidence in global governance processes. In Africa, norms such as enhancing capabilities, inclusion, common but differentiated responsibilities, social protection, and enhancing democratic participation need to be deepened at the domestic level, and genuinely form a cornerstone of deliberations at the global level.

South Africa has its own set of challenges. The country's energy-mix and shortfall is consistently identified as a key challenge to mitigation because of its high emissions and the crucial role it plays in the economy. Key themes for mitigating the effects of climate change and transforming the energy sector include developing capacities in renewable energies on a national scale as the country possesses some advantages particularly in wind and solar power. South Africa remains caught in a bind, with an economy that is growing at slow rates, unacceptably high levels of unemployment, and acute levels of inequality.

There has not been much advance in the debate on environmentally sustainable and inclusive growth. Much of the emerging debates are still predominantly driven in the North, whereas those that are from the South remain on the margins. Even for Sub-Saharan Africa, 
there is paucity of substantive policy proposals on how to make growth more sustainable and inclusive. In large part, the thinking about growth has not transcended beyond the existing paradigm and is still very much influenced by the Washington Consensus, albeit in its improved version. Yet it is important that post-global financial crisis, new terms and a different framework of conceptualising growth to emphasis sustainability and inclusivity is found.

Notes on Contributor: Dr Mzukisi Qobo is senior lecturer of International Political Economy at the University of Pretoria and deputy head at the Centre for the Study of Governance Innovation (Govlnn) at the same university. He would like to thank Elizabeth Sidiropoulos for comments made on the earlier draft of the paper; as well as the South African Institute of International Affairs for commissioning the paper.

\footnotetext{
${ }^{1}$ Rodrik, D, One Economics, Many Recipes: Globalization, Institutions and Economic Growth. Princeton: Princeton University Press, 2007.

${ }^{2}$ Fioramonti, L, Gross Domestic Problem. London: Zed Books, 2012.

${ }^{3}$ Fioramonti, L, Gross Domestic Problem. London: Zed Books, 2012.

${ }^{4}$ Elhanan, H., (2004), The Mystery of Economic Growth. Cambridge, Massachusetts: Harvard University Press, pp.3-9.

${ }^{5}$ OECD, Promoting Inclusive Growth. Paris: OECD, 2012.

${ }^{6}$ Rodrik, D, One Economics, Many Recipes: Globalization, Institutions and Economic Growth. Princeton: Princeton University Press, 2007, pp.16-17.

${ }^{7}$ Op.cit., p.17.

${ }^{8}$ Acemoglu, D \& Robinson, J, Why Nations Fail. Cambridge, Massachusetts:: Massachusetts Institute of Technology, 2011.

${ }^{9}$ Ngozi, O, Reforming the Unreformable: Lessons from Nigeria. Cambridge, Massachusetts: MIT Press, 2012, pp.119-122.

${ }^{10}$ Fioramonti, L, Gross Domestic Problem. London: Zed Books, 2012, pp.85-86.

${ }^{11}$ Sen, A, Development as Freedom. Oxford: Oxford University Press, 1999.

12 lbid., pp.91-92.

${ }^{13}$ UNDP (United Nations Development Programme). Human Development Report 2013: The Rise of the South Human Progress in a Diverse World. Geneva: UNDP, 2013, p.24.

${ }^{14}$ Fioramonti, L, Gross Domestic Problem. London: Zed Books, 2012, pp.90-91.

${ }^{15}$ OECD, Promoting Inclusive Growth. Paris: OECD, 2012.

${ }^{16}$ See Carbon Disclosure Project, 'Catalysing business and government action', https://www.cdproject.net/enUS/Pages/About-Us.aspx

${ }^{17}$ Stiglitz et al. Report by the Commission on the Measurement of Economic Performance and Social Progress, 2010. Internet: http://www.stiglitz-sen-fitoussi.fr/documents/rapport anglais.pdf. Access: 30 April 2012.

${ }^{18}$ Rotberg, Robert I, Africa Emerges. London: Polity, 2013, p.179.

19 Ibid: p.190.

${ }^{20}$ Frieden, J, Global Capitalisam: Its Fall and Rise in the Twentieth Century. New York: W.W Norton, 2007, p.450.

${ }^{21}$ Wolf, M, Why Globalisation works. Yale University Press, 2004, p.205.
} 
${ }^{22}$ Aliyu, Ibrahim, "Why Nigeria's Economic Growth Can't Stop Poverty, Inequality", Sunday Trust, 13 July 2013. http://sundaytrust.com.ng/index.php/business/13748-why-nigeria-s-economic-growth-can-t-stop-povertyinequality

${ }^{23}$ African Development Bank, Annual Development Effectiveness Review: Annual Review. Internet:

http://www.afdb.org/fileadmin/uploads/afdb/Documents/Project-and-Operations/ADER\%20(En)\%20\%20Websafe.pdf\#original. Access: 7 November 2012.

${ }^{24}$ UNECA (United Nations Economic Commission on Africa), Economic Commission on Africa: Annual report 2010. Internet: http://www.uneca.org/cfm/2010/documents/English/AnnualReport_2010.pdf\#original.

Access: 7 November 2012.

${ }^{25}$ Reference to the narrowest measure of standards of living - GDP - is only for indicative purposes as it is mostly utilised as a proxy for how well countries are doing in their ability to accumulate physical assets, and remains the most readily available indicator of economic growth trends.

${ }^{26}$ Ibid: p. 25.

${ }^{27}$ Ibid: p.26.

${ }^{28}$ World Bank, Economics of Adaptation to Climate Change - Synthesis Report. Washington D.C: The World Bank. http://documents.worldbank.org/curated/en/2010/01/16436675/economics-adaptation-climatechange-synthesis-report. Access: 5 August 2013.

${ }^{29}$ Governing development in Africa: The role of the State in economic transformation, UNECA Issues Paper, Addis Ababa, 24-27 March 2011, pp 1-11,

http://www.uneca.org/sites/default/files/page attachments/com2011 issuespapergoverningdevelopmentinafrica en.pdf (accessed 29 August 2013).

${ }^{30}$ Mkandawire, T. 2001. The need to rethink development economics. Draft paper prepared for discussion UNRISD meeting on 'The need to rethink development economics', Cape Town, South Africa, 7-8 September. ${ }^{31}$ Ibid.

${ }^{32}$ Rankin et al., 'The financial crisis and its enduring legacy for youth unemployment'. In Hofmeyr, J. ed. Transformation Audit 2012. Wynberg: IJR 2012, p.24.

${ }^{33}$ http://www.info.gov.za/aboutgovt/programmes/new-growth-path/ Access: 5 August 2013.

${ }^{34}$ http://www.info.gov.za/aboutgovt/programmes/new-growth-path/ Access: 5 August 2013.

${ }^{35}$ Department of Environmental Affairs and Tourism, National Climate Change Response Strategy. September 2004. http://unfccc.int/files/meetings/seminar/application/pdf/sem sup3 south africa.pdf Access: 5 August 2013.

${ }^{36}$ Government of South Africa, National Climate Change Response White Paper 2011.

http://d2zmx6mlah7g3a.cloudfront.net/cdn/farfuture/67-9DxoooolOTs-TUZNp ILHYxAwICzOKBVqydQ9yM/mtime:1318494015/files/docs/111012nccr-whitepaper.pdf Access: 5 August 2013. 